This item was submitted to Loughborough's Research Repository by the author.

Items in Figshare are protected by copyright, with all rights reserved, unless otherwise indicated.

\title{
The role of ICTs in the servitization and degradation of IT professional work
}

\section{PLEASE CITE THE PUBLISHED VERSION}

https://doi.org/10.1111/ntwe.12109

\section{PUBLISHER}

(c) Brian Towers (BRITOW) and John Wiley \& Sons Ltd

\section{VERSION}

AM (Accepted Manuscript)

\section{PUBLISHER STATEMENT}

This is the peer reviewed version of the following article: TRUSSON, C., HISLOP, D. and DOHERTY, N., 2018. The role of ICTs in the servitization and degradation of IT professional work. New Technology, Work and Employment, 33(2), pp. 149-170, which has been published in final form at https://doi.org/10.1111/ntwe.12109. This article may be used for non-commercial purposes in accordance with Wiley Terms and Conditions for Use of Self-Archived Versions.

\section{LICENCE}

CC BY-NC-ND 4.0

\section{REPOSITORY RECORD}

Trusson, Clive, Donald Hislop, and Neil Doherty. 2018. "The Role of Icts in the Servitization and Degradation of IT Professional Work". Loughborough University. https://hdl.handle.net/2134/32654. 


\title{
The role of ICTs in the servitization and degradation of IT professional work.
}

\begin{abstract}
Recently IT work has been subjected to management approaches that apply production methods to service work. Specialized ICTs used by IT professionals have played an important role in this 'service turn', but this has not been adequately explored in the literature. Via a qualitative study of IT professionals situated across the servitized IT functions of five UK-based organizations, this article considers how these ICTs are inscribed with managerial logics that afford control benefits to managers while undermining professional autonomy and job quality. The article makes two main contributions to the literature. Firstly, it sheds light on how ICTs introduced into organizational IT functions support managerial control objectives and impact the job quality of IT professionals. Secondly, it suggests that ICTs may infect the logic of professionalism that takes pride in the quality of the work performance with a dominant managerial logic that places an emphasis on meeting management objectives.
\end{abstract}

Keywords: professional work, autonomy, managerialism, IT Service Management, deskilling, control, servitization, job quality, IT workers 


\section{Introduction}

It has been, and remains, a function of information technology (IT) professional work to develop and support the information and communication technologies (ICTs) that have transformed the work of other professional workers. The IT profession has played an important role in enabling managers to impose a structure of ICT-enabled operational processes that 'incorporates the authoritarianism of the industrial workplace' (Winner, 1996, p.83), disciplining workers 'in accordance with the productivity ideal' (Alvesson, 1987, p.158) while simultaneously de-skilling them (Braverman, 1974; Kraft, 1977).

In this article focus is applied to the work processes of IT professional workers. It reports on how the de-skilling of IT professionals reported on by Kraft (1977) forty years ago is still observable in the servitized IT functions of today's organizations. It acknowledges that IT professionals, seeking to establish autonomy over their work, have struggled with managers seeking to routinize their work. However, by applying a contemporary focus it draws attention to the roles played by specific ICTs that are commonly imposed upon organizational IT functions by managers pursuing a 'servitization' agenda (Levitt, 1972; Conger, 2010). Via a study of IT professionals working across five UK organizations, the specific managerial purposes that are served by these ICTs are revealed.

This article will contribute to the academic literature in two important ways. Firstly, it will shed light on how role-specific ICTs simultaneously support the fulfilment of managerial control objectives (i.e. as opposed to technical-professional objectives) and reduce the job quality of IT professionals. Particularly, it is suggested that job quality degradation takes form through a loss of professional autonomy over the labour process and a reduction in the professional challenge (i.e. task complexity/ cognitive demands) (Holman, 2013). Secondly it acknowledges the role played by these ICTs, as important artefactual elements of a 
managerial discourse of servitization, in delivering a managerially-desired shift in professional logic. The suggestion is that the IT professional logic that emphasizes the quality and depth of the professional performance is infected by a managerial logic that emphasizes meeting quantitative performance targets written into service level agreements (SLAs) (Sennett, 2008; Sturm et al., 2000; Winniford et al., 2009).

The article continues with the following structure. First, to contextualize our study, we report on how IT professional work has increasingly been 'servitized', subjecting IT professionals to management techniques that aggrandize process definition and control via continuous performance monitoring. At the end of that section the research questions are specified. This is followed by a section that outlines and justifies the research methods employed. Our research findings are then presented and discussed in situ followed by a section that further discusses the study in terms of how it contributes to the literature. The article concludes with suggestions for future research directions and draws attention to the study's limitations.

\section{The Servitization of IT Professional Work}

In the early stages of the development of organizationally-situated computer/IT work, the focus of the work was primarily on the technological design and development of IT systems. Management of such work was typically focussed on the technology being developed (Winniford et al., 2009) and the management literature concerned itself with 'developing techniques to get the people [that] managers manage to do what they are told' (Kraft, 1977, p. 4). There was a recognition here that managerial control of the IT professional labour process was often weak. Developers/programmers had to follow the rules of coding language(s) but otherwise needed considerable autonomy over extended time periods to meet management deadlines for delivery of acceptable programs. 
Alongside interest in the development and management of IT systems, academics studying workers within IT functions have particularly examined the practices of developers/programmers as 'critical people whose role... is... little appreciated' (Kraft, 1977, p. 2; Barley and Kunda, 2004; Marks and Scholarios, 2007; Bergvall-Kåreborn and Howcroft, 2013). As such, the literature on the IT profession has mainly focussed on work that is performed before IT systems are implemented. This may present a skewed picture of work in the contemporary organizational IT function. As IT systems have become ubiquitous across organizations of all sizes, such that they are 'an intrinsic part of... business practices and government activities and service provision' (Greenhill, 2011, p.v), so most organizations are now primarily concerned with the maintenance and support of 'live' IT services they rely upon to trade/function. As such the centrality of the programmer writing new code has given way to the centrality of the IT support worker ensuring availability of IT services by maintaining systems and resolving incidents.

The term 'servitizing IT' was coined in the academic literature by Conger (2010) to denote the trend towards emphasising customer-oriented service in the delivery of business IT solutions. The scant academic literature on organizational IT provision following this 'service turn' (Iden and Eikebrokk, 2013) essentially responds to ideas that had taken hold among an IT service management (ITSM) practitioner community, having been diffused via discursive practice and practitioner literature (e.g. Bartlett et al., 2001; Stroud, 2011). Particularly significant are the techniques described in the ITIL (formerly, Information Technology Infrastructure Library) ‘best practice’ literature (e.g. Bartlett et al., 2001; Steinberg, 2011).

ITIL has evolved from being a set of IT management guidelines for UK civil servants in the late 1980s to be an internationally-diffused and trademarked managerial framework for conceiving IT systems as services and managing them accordingly (Iden and Langeland, 2010). While there are alternative models of ITSM 'best practice' (e.g. DevOps and COBIT), 
ITIL dominates as the global 'gold standard' (Rae, 2017). As such it has been globally adopted by IT managers acting from a shared position of collective rationality (Dimaggio and Powell, 1983), with endorsements across the technology business landscape: from iconic US organizations such as IBM (So and Bolloju, 2005) and Hewlett Packard (2002) to leading Indian IT service providing companies such as TCS Computer Services (2017) and Wipro (2017).

Partly, the rise of ITIL responds to the increasing complexity of organizational IT systems (Pollard and Cater-Steel, 2009); and partly, it incorporates and reflects contemporary neoTaylorist managerial approaches, including 'Total Quality Management' (Feigenbaum, 1986) and 'Lean' (George, 2003). These approaches are applied to the provision of IT services (Levitt, 1972; Conger, 2010) such that control is asserted via defined standardized processes that interact within a system designed to fulfil customer needs (Steinberg, 2011).

The IT professional working in the servitized IT function is likely to be working within imposed ITIL processes (notably: Incident Management; Change Management and Problem Management) on a succession of queued tasks (Russell et al, 2016). As with other workers who work in such a way (i.e. completing one task after another), ICTs might usefully be employed to enact managerial control over these workers.

Further, within this servitized working environment IT professionals are expected to take on roles of 'servants' to their rationally-defined 'customers' who are notionally assigned 'mythical' sovereignty over them (Korczynski, 2002). This customer-servant relationship is presented to workers as being sacrosanct within a creedal SLA that is negotiated and agreed at a rational business-to-business level between the managements of the service provider and service recipient. The SLA, as a feature of rationalized service level management (Sturm et al., 2000), sets out the performance levels to be met by the employees of the service provider 
and is thereby central to the servitization of the IT function. It determines the worker performance data that ICTs need to capture so that IT service managers can show that service levels are being met. As such it is a mechanism for asserting greater pressure/control over IT professionals who provide the 'expert' service for the service provider.

In the servitized IT function workers are overtly commodified as 'people assets', such that their 'productive capacity' might be measured 'in units of cost, time and effort' (Cannon, 2011, p.382). Similarly, workers' capabilities are commodified as 'knowledge assets': 'accumulations of awareness, experience, information, insight and intellectual property' such that they 'can be highly leveraged' (Rance, 2011, p.67). This commodification underpins the 'outsourcing' and 'offshoring' of corporate IT work to specialist IT service providers, especially in India (Standing, 2011). Of pertinence to this study, ITIL 'best practice' also advocates the management imposition of work process-defining applications software. This supports the servitization of the IT function by standardizing the '[performance of] specific tasks and information processing activities' (Turban et al., 2001, p. 129), and by providing, via database technologies, ready access to technological and operational information/knowledge (Steinberg, 2011). The academic literature has yet to adequately explore the effects of such ICTs on the nature of IT professional practice, with only implicit acknowledgement of it having changed (Cater-Steel, 2009).

Despite the widespread servitization of IT functions, the expertise of IT professionals remains 'crucial' within them (Bapna et al., 2013) albeit that there may be a lesser expectation of skills competency today than in previous eras (Hawk et al., 2012). While technical information systems work has long been attributed professional status (Evetts, 2003), by adopting a trait-based perspective on professions (Muzio et al, 2013), IT professionals working in servitized IT functions retain multiple traits associated with organizationallysituated professional workers. Firstly, their work is socially significant (Brock et al., 2014). 
Secondly, they are required to exercise 'superior' technological expertise (Larson, 1977, p.185) underpinned by a body of theoretical knowledge (Fincham, 2006). Thirdly, they exercise an 'ability to grasp new events quickly and to respond effectively' (Broadbent et al, 1997, p.51) using professional inference (Abbott, 1988) or creativity (Cohen et al, 2005). Fourthly, their technical expertise affords them both diagnostic authority (Johnson, 1972) and the trust and obedience of those benefiting from their expertise (Starr, 1982). Finally, they '[solve] core problems for their employers' (Muzio et al, 2013, p.710).

However, in opposition to these traits attributing professional status to IT workers, the servitization of IT functions via the implementation of ITSM 'best practices' may point in the direction of IT work becoming more akin to info-service work (Russell, 2009). Whereas the literature has often painted a picture of IT work as a prestigious domain of tech-experts, most notably in Barley and Kunda's (2004) classic ethnography of 'gurus' and 'hired guns', this may not reflect the experience of workers in servitized IT functions. Their work might be better presented as commodified labour practiced within management-defined work processes that mandate use of ICTs.

Significantly for this study, ITIL, as a mechanism of IT servitization within an organization, is enthusiastically promoted by the UK's leading IT professional body, 'BCS, the Chartered Institute for IT' (BCS). By implicitly accommodating the managerialist values inscribed within ITIL, the BCS opens itself up to accusations of complicity in degrading the quality of jobs within the IT profession. There is a clear suggestion of self-exploitation in advocating the commodification of IT professionals within the systems model and the imposition of ICTs (produced by other IT professionals) to facilitate 'commercial business growth' (BCS, 2009). The proposition here is that the ITSM servitization discourse has significantly influenced the IT professional discourse. With reference to Spence and Carter's (2014) distinction between professional logics concerned with technical practice and the commercial aspects of that 
practice, our study considers the role of ICT-enabled work processes in infecting the technical-professional logic that was foundational to the IT profession with a customerfocused managerial logic.

As such, the first research question addressed by the study was:

RQ1) What managerial purposes are inscribed/camouflaged within ICTs commonly used by servitized IT professionals?

The objective of this question was to reveal the camouflaged managerial control logics (Callaghan and Thompson, 2001) that were inscribed within ICTs used by a research population of IT professionals working within servitized IT functions.

A second related research objective was to better understand how such ICTs affected the capacity of IT professionals to exercise autonomy over their 'servitized' working practices. Given the generally-accepted associations between, on the one hand, job quality and professional status, and, on the other, autonomy, and that increased managerial control threatens autonomy (Ashburner and Fitzgerald, 1996) our study addressed the following research question:

RQ2) How might ICTs used by servitized IT professionals place restrictions upon individual autonomy?

Additionally, given the long-accepted notion that professional work cannot be readily rationalized because of difficulties associated with knowledge complexity (Freidson, 2001), the study also addressed the following research question:

RQ3) How might ICTs used by servitized IT professionals effectively capture professional expertise for managerial control and corporate re-use? 
The research model presented in Figure 1 illustrates the relationship between these three research questions. Overall, this empirical study is positioned to offer new insights into how job quality within the IT profession may be degraded by ICTs that IT professionals are required to use. In the next section we outline how we went about addressing these research questions.

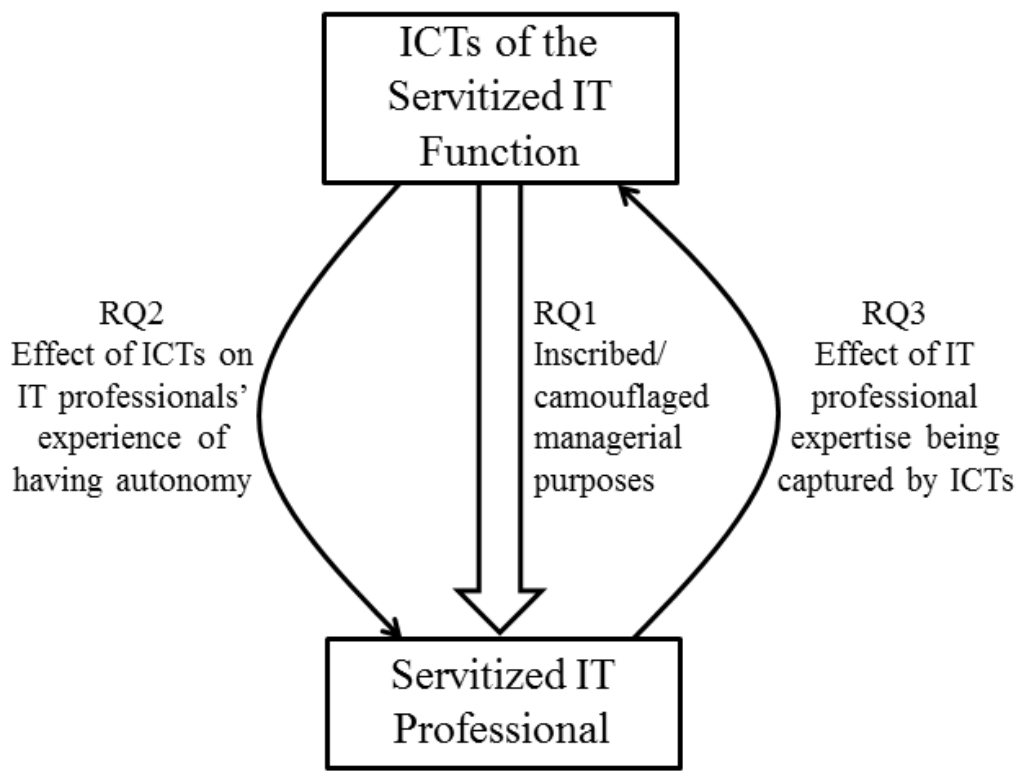

Figure 1: Research Model

\section{Research Methods}

In this section, we outline the qualitative, multiple case study, research strategy adopted for this study of IT professionals using ICTs as a phenomenon of interest operating in their natural social context (Eisenhardt, 1989) of the servitized IT function of an organization. The five organizations selected as data collection sites all managed IT systems according to ITSM 'best practice' (i.e. ITIL) (Table 1). Researching across organizations enabled cross-case analysis. By comparing these cases that shared a defined social domain (i.e. the servitized IT function) greater assurance was provided regarding the analytical generalizability and robustness of the research to provide a stronger base for recognizing emergent theory (Eisenhardt and Graebner, 2007; Miles and Huberman, 1994; Yin, 2014). For this study, both 
observation data and interview data were collected and independently analysed, as discussed further below.

Both datasets were analysed by the first author from a Schutzian 'shared lifeworld' (Lebenswelt) perspective. This entailed reflexively acknowledging that, while individuals possess unique 'stocks of knowledge' so that at any moment they are in 'a biographically determined situation' (Schutz, 1970, p.73), these 'stocks of knowledge' are 'socially derived and transmitted to the individual' over time within social domains that are shared with others (Schutz, 1966, p.120). The social domain here is the servitized organizational IT function. Thus, this 'life world' perspective points to there being a 'stock' of experientially-formed knowledge concerning organizationally-based IT service work that is familiar to both the researcher and the research participants. In this study the researcher brought to the task of data collection and analysis 15 years' experience of working as an IT professional (most recently working in the servitized IT function of a corporation and as an accredited 'ITIL Expert' educator). This afforded him interpretations of data founded upon a 'stock of knowledge' from within the IT service 'life world' shared with the research participants. This perspective shares similar benefits to those of the 'insider researcher' perspective whereby 'researchers [who] are native to the setting... have insights from the lived experience... Because we are close to something or know it well... we can research it... [and provide] important knowledge about what organizations are really like' (Brannick and Coghlan, 2007, pp.60,72).

\section{Collection and Analysis of Observation Data}

Observation data were collected over 34 days. During this period of data collection, 20 IT professionals working in servitized IT functions were observed processing 90 IT service incidents within defined incident management (IM) processes (Table 1). 


\begin{tabular}{|c|c|c|c|c|c|}
\hline $\begin{array}{l}\text { Organization } \\
\text { (Pseudonym) }\end{array}$ & $\begin{array}{l}\text { Brief } \\
\text { Description }\end{array}$ & $\begin{array}{l}\text { IT Systems } \\
\text { supported }\end{array}$ & $\begin{array}{l}\text { Days of } \\
\text { Observation }\end{array}$ & $\begin{array}{l}\text { Number of } \\
\text { Workers } \\
\text { Observed }\end{array}$ & $\begin{array}{l}\text { Number of } \\
\text { Workers } \\
\text { Interviewed }\end{array}$ \\
\hline $\begin{array}{l}\text { Shire County } \\
\text { Council (SCC) }\end{array}$ & $\begin{array}{l}\text { Public sector } \\
\text { service } \\
\text { provider }\end{array}$ & $\begin{array}{l}\text { Complex } \\
\text { arrangement of } \\
\text { IT components } \\
\text { supporting local } \\
\text { government } \\
\text { operations }\end{array}$ & 12 & 9 & 10 \\
\hline Stoneworks & $\begin{array}{l}\text { UK } \\
\text { operation of } \\
\text { large multi- } \\
\text { national } \\
\text { aggregates } \\
\text { company }\end{array}$ & $\begin{array}{l}\text { Complex IT } \\
\text { infrastructure of } \\
\text { the UK } \\
\text { operation }\end{array}$ & 7 & 4 & 6 \\
\hline Server Control & $\begin{array}{l}\text { UK } \\
\text { operation of } \\
\text { multi- } \\
\text { national } \\
\text { company } \\
\text { providing IT } \\
\text { security } \\
\text { services }\end{array}$ & $\begin{array}{l}\text { Multiple } \\
\text { bespoke } \\
\text { independent IT } \\
\text { systems }\end{array}$ & 6 & 3 & 4 \\
\hline Poyet Systems & $\begin{array}{l}\text { SME } \\
\text { providing } \\
\text { military } \\
\text { software }\end{array}$ & $\begin{array}{l}\text { Company IT } \\
\text { infrastructure } \\
\text { and applications } \\
\text { supplied to } \\
\text { clients }\end{array}$ & 5 & 2 & 3 \\
\hline $\begin{array}{l}\text { Midlands } \\
\text { University }\end{array}$ & $\begin{array}{l}\text { Mid-sized } \\
\text { university }\end{array}$ & $\begin{array}{l}\text { Complex IT } \\
\text { infrastructure } \\
\text { supporting } \\
\text { university } \\
\text { operations }\end{array}$ & 4 & 2 & 3 \\
\hline \multicolumn{3}{|r|}{ Totals } & 34 & 20 & 26 \\
\hline
\end{tabular}

Table 1: Organizational Context of Study.

Extensive notes were taken by a single researcher: the first author of what the IT professionals were doing and what ICT tools they were using. These notes were later converted into detailed data records representing the activity performed by the IT professionals. 
Particular attention was given to observing the ICT tools that the servitized IT professionals used in their everyday practice. In broad terms these tools might be classified as applications software enabling specific task performance and information processing (Turban et al., 2001) and/or database technologies enabling electronic storage and retrieval of data/information/knowledge. The notes taken were analysed with the objective of classifying these ICTs according to their intended purposes and functional benefits. The starting point for this analytical process was a consideration of each of the identified ICTs in relation to existing ICT classification schemas. Specifically, we drew upon schemas offered by McAfee (2006) and Orlikowski and Iacono (2001). McAfee (2006, p. 145) identifies three high-level categories of organizational IT that change the way that work is performed: 'Function IT... that assists with the execution of discrete tasks' (e.g. spreadsheets), 'Network IT... that facilitates interactions without specifying parameters' (e.g. email), and 'Enterprise IT... that specifies business processes'. Orlikowski and Iacono (2001) note how technological artefacts might be understood to have four distinct purposes when conceptualized from a 'black box' tool view of technology. Firstly, they might serve to substitute for or replace labour. Secondly (and relatedly), they might serve to enhance the productivity of labour. Thirdly, they might improve upon the mechanisms by which organizational information is processed and communicated; and/or fourthly, they might alter social relations within the organization, specifically by enabling more productive/efficient business processes.

For our study we were similarly interested in identifying the intended (i.e. designed-in) effects but our specific interest was in analysing and reporting on the observable ICT tools in terms of how they applied 'camouflaged' technological control (Callaghan and Thompson, 2001) over the practices of IT professionals. As such, during our process of data analysis, we drew upon labour process theory debates on managerial control mechanisms, de-skilling, and work fragmentation (e.g. Braverman, 1974; Edwards, 1979; Thompson, 1989). The 
management-mandated (via ITIL 'best practices') work processes that the IT professionals worked within (using ICT tools) are identifiably examples of structural technical management control being asserted through the separation of the conception and execution of labour (Braverman, 1974). More specifically, Edwards (1979, p.112) identifies three elements of such systems of control: 'direction of work tasks, evaluation of work done, and rewarding and disciplining workers'. By analysing the data from this theoretical perspective, we induced a new schema for classifying ICTs. In this schema four managerial control logics were identified as being 'inscribed' (Howcroft and Light, 2006), 'embedded' (Edwards, 1979), and/or 'camouflaged' (Callaghan and Thompson, 2001) within the design of ICT tools used by IT professionals (Table 2).

\begin{tabular}{|l|l|}
\hline Managerial Control Logic & Intended Effect \\
\hline Prescription & $\begin{array}{l}\text { to assert control over the work/labour process by prescribing } \\
\text { what work is performed by IT professionals, and/or how. }\end{array}$ \\
\hline Surveillance & $\begin{array}{l}\text { to assert technological supervisory power and control through } \\
\text { monitoring and measuring within the confines of the defined } \\
\text { work/labour process. }\end{array}$ \\
\hline Constraint & $\begin{array}{l}\text { to control the workforce's activities by placing physical } \\
\text { restrictions upon them within the defined work process and/or } \\
\text { by restricting access to technologies and data according to } \\
\text { process-defined roles. }\end{array}$ \\
\hline Knowledge capture & $\begin{array}{l}\text { to stimulate the codification and capture of IT professionals' } \\
\text { expertise; to bring objectified knowledge under management } \\
\text { control. }\end{array}$ \\
\hline
\end{tabular}

Table 2: Managerial control logics inscribed in ICT tools in servitized IT functions

This schema constitutes an additional incidental theoretical contribution. It is employed in the reporting of the findings below to show how the ICTs, that management mandated IT professionals to use, asserted these managerial control logics within the labour processes. 


\section{Collection and Analysis of Interview Data}

In addition to the observation of IT professionals, 26 (including 15 of those observed) were also interviewed at their workplaces (Table 1). A semi-structured interview technique was employed to access workers' 'descriptions, rationalizations and reflections' on their everyday work experience (Bloor and Wood, 2006, p.71). The interview transcriptions were manually analysed by the first author through a process of reading, reflecting, open coding (Emerson et al, 1995) and modelling to identify 'a fragile web' of potential themes and patterns (Padgett, 1998, p.77) relating to the meanings that the participants attached to their everyday work experiences. The most significant of these themes were established through an iterative process of re-reading, comparing the transcriptions to 'separate the [thematic] wheat from the chaff' (Padgett, 1998, p.77), and formalized discussion between the co-authors. Specifically, lower-level coding was applied to interview data that had been thematically identified as pertinent to how servitized IT professionals talked about using and relating to ICTs in their practice. This lower-level coding associated the extracted interview data with the specific technologies that were identified as being integral to the work. To enhance analytical rigour, an iterative collaboration process was followed whereby the first author presented formative argument and theory to the co-authors for discussion and challenge.

\section{Managerial Control of IT Professionals via ICT Tools}

In this section our findings are reported and discussed in situ. This section is structured in three parts. Firstly, in response to RQ1, we report on the ICTs significant to this study, situating them within the managerial control logics analytical schema discussed above. This is followed by findings related to RQ2 that reveal how specific ICTs enact managerial control upon workers such that autonomy is adversely affected. Finally, in response to RQ3, we 
report on how individual discretionary behaviour limited the inscribed managerial intent of ICTs designed to capture professional expertise for corporate reuse.

The observed research participants supported a variety of IT systems (Table 1). In doing so they worked within tightly-defined processes structured in alignment with the functional designs of specialized ITSM applications. These integrated packages comprised various technologies including computer telephony integration technology, databases, workflow management systems, system-generated work queues, and statistical reporting technology. It is these integrated ICT tools, and other obligatory ICT tools that are the focus of this study (i.e. rather than the 'customer' ICTs maintained and supported by the research participants). This section continues in three parts relating to the research questions.

\section{ICTs used in servitized IT professional practice, and their inscribed managerial control logics}

The primary tools for the research participants were integrated specialist ITSM ICTs designed to support a 'best practice' IM process comprising several sequential steps: incident logging, classification, investigation, diagnosis, resolution, and closure (Steinberg, 2011). These tools were functionally similar across the organizations. Additionally, other ICTs were observed: role-based access control systems; remote access software; and self-help knowledge databases. These ICT tools are listed in Table 3. This categorizes them according to the McAfee (2006) schema and briefly describes the functionality of each tool with reference to the Orlikowski and Iacono (2001) schema. It also classifies each tool according to our inscribed managerial control logics schema discussed above (Table 2). We make useful reference to this schema in the following sub-sections that, in responding to RQ2 and RQ3, also add substance to the managerial control logic classifications that we have applied to each of the identified ICT tools in Table 3. 


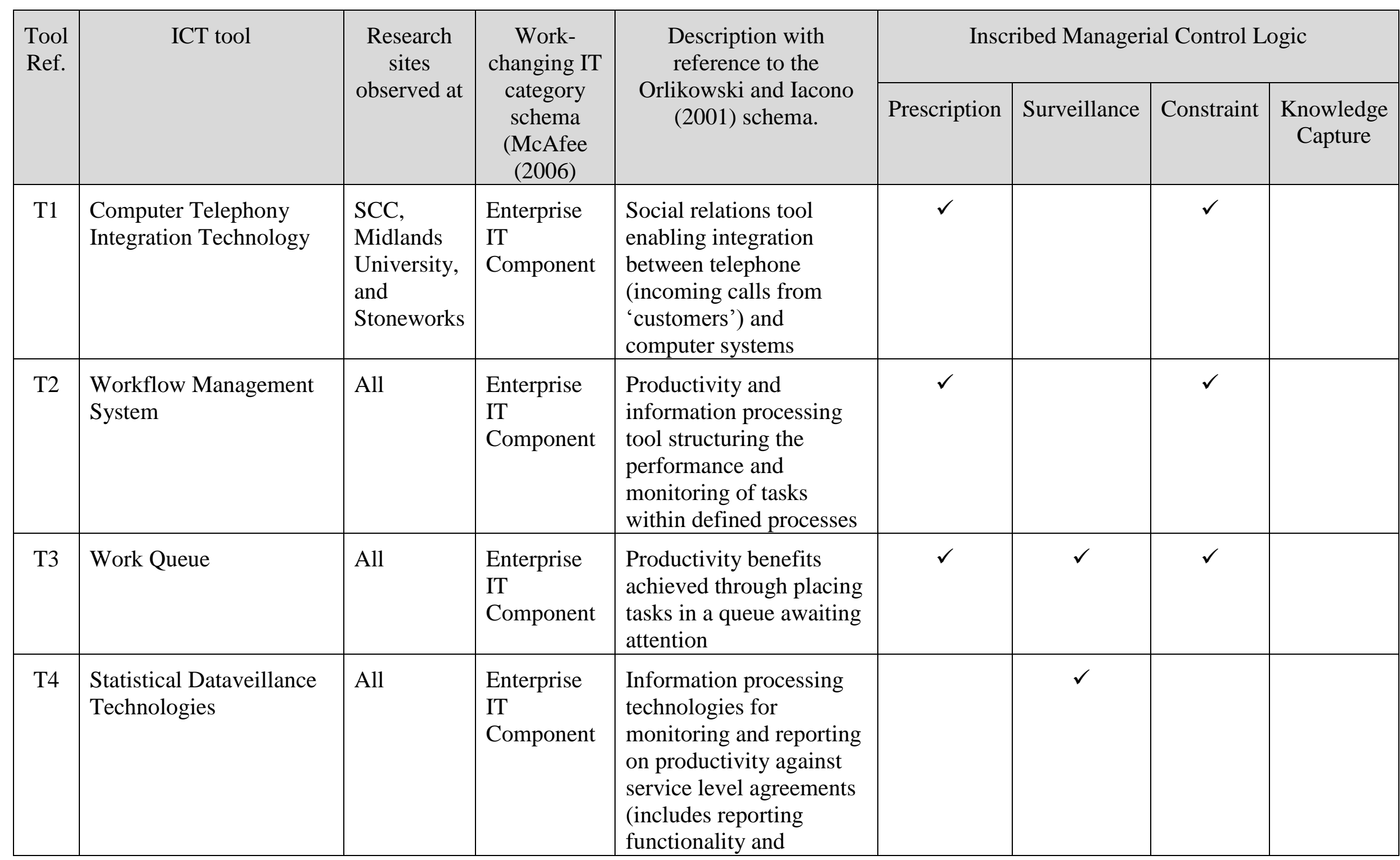




\begin{tabular}{|c|c|c|c|c|c|c|c|}
\hline & & & & $\begin{array}{l}\text { Red/Amber/Green } \\
\text { dashboards) }\end{array}$ & & & \\
\hline T5 & Remote Access Software & All & Function IT & $\begin{array}{l}\text { Productivity and social } \\
\text { relations tool enabling } \\
\text { provision of IT support } \\
\text { without workers leaving } \\
\text { their workstations. }\end{array}$ & $\checkmark$ & $\checkmark$ & \\
\hline T6 & $\begin{array}{l}\text { Role-based Access } \\
\text { Control System }\end{array}$ & All & Function IT & $\begin{array}{l}\text { Database that places } \\
\text { controls over what parts } \\
\text { of IT systems workers } \\
\text { can work on and what } \\
\text { tools they can use }\end{array}$ & & $\checkmark$ & \\
\hline $\mathrm{T} 7$ & Incident Record Database & All & $\begin{array}{l}\text { Enterprise } \\
\text { IT } \\
\text { Component }\end{array}$ & $\begin{array}{l}\text { Information processing } \\
\text { repository of uniquely- } \\
\text { referenced units of IT } \\
\text { work (completed and in- } \\
\text { progress); accessed via } \\
\text { interface application }\end{array}$ & $\checkmark$ & & $\checkmark$ \\
\hline T9 & $\begin{array}{l}\text { Self-Help Knowledge } \\
\text { Database }\end{array}$ & All & Network IT & $\begin{array}{l}\text { Labour substitution tool } \\
\text { enabling service users to } \\
\text { attempt resolution of } \\
\text { incidents using }\end{array}$ & & & $\checkmark$ \\
\hline
\end{tabular}




\begin{tabular}{|l|l|l|l|l|l|l|}
\hline & & $\begin{array}{l}\text { 'knowledge articles' } \\
\text { provided by IT } \\
\text { professionals }\end{array}$ & & \\
\hline
\end{tabular}

Table 3: Managerial control ICTs within the servitized IT function 
What emerges from this analysis is a sharper awareness of how and why managers of servitized IT functions mandate work processes that rely upon multiple ICT tools.

Specifically, we might observe how, in combination, these tools exercise considerable authoritative agency over those work processes (Winner, [1980], 1999). It can therefore be shown that the ICT tools are central to how managers assert 'coercive workplace power' (Thompson, 1989, p.122) as they seek to achieve technical control such that 'their' workers will consistently display appropriate and disciplined work behaviours (Edwards, 1979). The findings illustrate how ICTs serve this managerial purpose through the prescription of the labour process (e.g. what work IT professionals are directed to perform that is additional to their technical-professional practice), the application of physical and mental constraints (e.g. where they must be situated, and what task they must pick up next to work on), and performance monitoring (e.g. how many incidents they have resolved and how they have resolved them). It also illustrates how managers seek control over individual 'stocks of knowledge' (Schutz, 1970) by providing ICTs designed to objectify and capture the technical knowledge of IT professionals.

\section{The Impact of ICTs on the Autonomy of IT Professionals.}

The observation data across all organizations revealed an implicit managerial assertion of protocol: that workers must utilize the integrated ITSM tool. As such, the everyday experience of these workers was structured (i.e. prescribed) according to a pre-determined process that constrained the discretion afforded to the research participants. In the design of the work process 'the incident' (i.e. the reported service issue) is reified as a computer record and positioned as the central entity travelling through a process that is 'powered' by the integrated ITSM tool (Steinberg, 2011). The IT professional, objectified as a system resource, is subordinate to 'the incident' and required to consent and conform to the directives and monitoring of the ICTs. It is as Edwards (1979, p.125) wrote of technical control: 'in this 
dazzle of new technology the workers are almost lost from sight'. Here we bring them back into view.

Through observation it was seen that the workflow management technology provided a structural framework that ensured tasks were performed according to inscribed procedural rules, in the right order, by the right people (Bocij et al, 2008). As such they are identifiable as tools that, in rationalising the work process into distinct stages, embody managerial control logics of process prescription and worker constraint (Table 3: Ref. T2). Thus, the workflow management system demanded that IT professionals enter considerable incident-related data as a mandatory procedural task.

We have to record why we are logging a call, so, classify it... and the area, but that's very vague... and I think most people log them incorrectly... the status of the individual, how difficult the job is, or how business critical it is... different criteria. (Charles, IT Desktop Analyst, Stoneworks)

The interview data reveal worker frustration that their autonomy was restricted by this technological assertion of agency (Winner, [1980] 1999): demanding they spend time on administrative tasks that served a managerial demand for control and metrics, and overriding their preference for spending time in technical-professional expression:

You will find that most engineers hate to do the paperwork, that side of things... Most of them have got the mentality of: 'It's the paperwork. It's not my job'... It can take you 10 minutes to raise the ticket... At the end of the day, I'm here to come in and fix people's problem. (John, System Support Engineer, Poyet)

Sometimes I feel that we are collecting data that is not necessary... I don't 
like to do things for the sake of it... [I get satisfaction from] resolving an issue, getting to the bottom of it... learning something new. That's what gives me the buzz. (Charles, IT Desktop analyst, Stoneworks)

Our interpretation is that, seeing themselves as expert technicians experiencing workload pressures, their interest was in using and developing their expertise during that 'pressured' time rather than in providing data for managerial purposes.

The data generated in this manner, along with quantitative data generated by the system, enabled reports to be produced to support management decision-making and/or facilitate charging for services (Table 3: T4). Specifically, such management reports provided information on performance against SLAs (Hunnebeck, 2011) that had been agreed between IT service managers and the managers of multiple internal customer business units. For example, a monthly Stoneworks IM report stated the percentage of incidents resolved against SLAs over the previous quarter (Table 4), without regard to the actual number of incidents processed.

\begin{tabular}{|c|c|c|c|c|}
\hline $\begin{array}{c}\text { Resolution } \\
\text { Target 90\% }\end{array}$ & $\begin{array}{c}\text { Critical } \\
\text { (4 hours) }\end{array}$ & $\begin{array}{c}\text { High } \\
(\mathbf{1 2} \text { hours })\end{array}$ & $\begin{array}{c}\text { Medium } \\
\text { (3 Days) }\end{array}$ & $\begin{array}{c}\text { Low } \\
\text { (1 week) }\end{array}$ \\
\hline December & $100 \%$ & $83 \%$ & $83 \%$ & $96 \%$ \\
\hline January & $100 \%$ & $80 \%$ & $74 \%$ & $94 \%$ \\
\hline February & $75 \%$ & $93 \%$ & $82 \%$ & $96 \%$ \\
\hline
\end{tabular}

Table 4: Extract from Stoneworks’ Incident Management Monthly Report: Incident Resolution Performance against SLA's 
Additionally, as evidenced later, many of the participant IT professionals were observed regularly monitoring their team's performance against SLAs in real-time via overhead Red/Amber/Green (RAG) dashboards (Table 3: T4). Thus, we found that the integrated ITSM ICTs not only structured the labour process but also generated performance metrics periodically and in 'real time'. This technological managerial surveillance of work activity referred to by Clarke (1988) as 'dataveillance' - is commensurate with the information panopticon analogy discussed by Zuboff (1988, p. 356), surreptitiously applying management pressure to meet rational systems' productivity demands. Such pressures were exemplified by Ravi, a technically-proficient team leader of IT professionals:

You always need to work hard in order to meet any SLA's or any KPI's [key performance indicators] ... you've got to make sure that the guys... actually want to meet the targets... We're struggling to meet our targets with the systems that we support now and obviously they are adding on more and more stuff and you just can't do it. (Ravi, IT Service Desk Supervisor, Stoneworks)

Contrary to Brock's (2006) suggestion that ICTs applied to professional work might offer a reduction in labour intensity, the data here point to the ICTs combining to exert disciplinary agency (Winner, [1980] 1999) to apply time pressures within self-managing teams (Katzenbach and Smith, 1994). Both the observation data and interview data capture a common experience of the work queue playing a central role in feeling pressured. This is illustrated in the following dialogue between two of Ravi's team: Asghar and James. At the time of the exchange they had handled 60 calls requesting support for IT incidents in a 90minute period:

James: Do you think we could do this all the time?

Asghar: We're doing it aren't we? ... There's 20 [incidents] waiting in the box. 
James: How are we supposed to do both?

We additionally report here that, as well as constantly taking calls reporting incidents and noting the queue of incidents reported by email, they both regularly looked at the overhead RAG dashboard to see how many phone calls were queued (Table 3: T4). In interview later Asghar (Service Desk Analyst, Stoneworks) admitted that:

It can get on top of you... when it gets really busy, when the monitors show that; when the calls are queueing... when you just know you're bogged down with so much to do and you just have to keep taking these calls... We have SLAs... [and] as you can see our board is always red.

Gareth (Support and Installation Engineer, SCC) and Navinda (IT Senior Analyst, Midlands University) similarly reported on the significance of the work queue (Table 3: T3). Gareth surmised that he would 'be brought up about it' if the queue built up, while Navinda talked about always 'try[ing] to catch up' with the work on the queue.

While peer-level surveillance was apparent, team leader-level supervisors also saw it as a significant part of their role to monitor performance via the work queues:

So long as the tickets are picked up [from the work queue] in a reasonable timeframe, I'm happy. (Nigel, Support Manager, Server Control)

While the overhead RAG dashboards were not in evidence at all sites, there was a universally pervasive awareness of supervisory monitoring of the work queues, and performance against SLAs. Tom (Team Leader, Corporate Desktop Services, SCC) commented: 'It's like you know there is monitoring, and you expect there to be... but it's not in your face at all'. John 
(System Support Engineer, Poyet) commented similarly but made specific reference to the integrated ITSM software, describing it in Orwellian terms as a 'kind of, you know, "Big Daddy is watching you" type of system'.

Across the whole research population, time pressures indirectly generated by the work queue, workflow management, dataveillance, and computer telephony integration technologies (Table 3: T1-T4) could be seen to have an impoverishing effect on individual professional autonomy. These technologies are like those found in call centres that previous research has found to 'pressurize' workers (Callaghan and Thompson, 2001, Woodcock, 2017) through the 'speed-up and intensification of work' (Taylor and Bain, 1999, p.108). This experience of feeling 'under pressure' impacted upon the IT professionals' capacities to thoroughly investigate technical issues and restricted opportunities to develop professional expertise. Stephen, an experienced IT professional at SCC, reported how he was constantly aware of the workload building up because this information was constantly being provided by the work queue technology (Table 3: T3). He explained how this affected his practice and impacted upon his capacity to express his technical-professional inclinations (Spence and Carter, 2014). It determined how he approached a task: whether to just do a quick fix that would not address the underlying issue or spend more time investigating the root cause so that similar incidents would not recur:

You can get an interesting problem and... almost see where it's going to go and what the problem is going to be, but the time to get from starting point to resolution is going to be too long. So, you think, 'Okay, so we just put that on the back burner and possibly come back to it, but for now just fix the problem and get it back to the customer' (Stephen, Support and Installation Engineer, SCC) 
This illustrates how an IT professional's awareness of the work queue may constrain their autonomy to choose the depth of their technical investigation. The suggestion here is that the 'quick fix' is less cognitively demanding of the IT professional, and thus, job quality is degraded (Holman, 2013).

Role-based access control systems, which are implemented to enact technical divisions of labour (Webster, 1990), were similarly identified as constraining autonomy. Our data analysis revealed how these systems were employed as control mechanisms denying particular IT professionals, in particular roles defined within particular processes, from performing particular technical tasks (Table 3: T6). This impacted upon several workers who had gained professional credentials and were striving to self-direct a career in IT through building up their practical experience. For example, Jonathan reported his frustration at the technological controls placed upon him by the organizational structuring that was inscribed within the settings of the role-based access control tool.

What I find frustrating is that in my head I've got a lot of technical knowledge and a lot of ability to do stuff, but just not having the tools and rights and access to do them, it's very frustrating because, you know, the job satisfaction kind of goes down a bit. (Jonathan, Senior IT Service Desk Analyst, Midlands University)

Where they did have access rights, IT professionals were expected to take control of users' IT systems using remote access software to investigate, diagnose and resolve incidents (Table 3: T5). When working using remote access tools, the IT professionals were constrained to the environs of their workstation (i.e. rather than being able to visit the site of the incident). Further, drawing parallels with low-status call-centre workers (Taylor, 2015), for some IT professionals, further spatial constraint was technologically applied by mandating that they be 
connected to their desktop computers by a wired headset that interacted with the computer telephony integration technology (Table 3: T1).

\section{The Appropriation of IT Professional Expertise for Corporate Reuse via ICTs}

In response to our third research question, we also identified ICTs that served a managerial purpose of digitizing workers' knowledge so that that commodified 'expertise' might become a corporate resource, thus undermining the professional workers' roles as solvers of organizational problems (Table 3: T7, T8, T9) (Muzio et al, 2013).

The 'best practice' that had been adopted at all five organizations (i.e. ITIL) advises managers to encourage the capture of 'valuable knowledge assets' in a knowledge management database system (Table 3: T8) (Rance, 2011, p.242). Accordingly, management at all sites had introduced knowledge database tools to be used for codifying technical knowledge/know-how. As such, managerial intent to control knowledge and so be less reliant upon knowledgeable individuals was universally apparent. Karla, the IT Service Manager at Stoneworks illustrated this managerial perspective: 'When somebody closes an incident and there isn't an article in the knowledge database, I'd want them to create one'.

Ideally, from the managerial perspective of cost-minimization, 'users' experiencing incidents would choose to investigate, diagnose and resolve them themselves by referring to a self-help knowledge database (Table 3: T9) (Steinberg, 2011). This technology relies upon commodified expert knowledge being made available to users thus removing the professional from the technical support process and transferring the labour activity to the 'consumer' (Fournier, 2000). Self-help arrangements at the IT service-providing organizations studied here were observable but limited to rudimentary web pages. However, a managerial intent to shift responsibility for incident resolution to system users, making use of the IT professionals' captured expertise was apparent. 
Where we want to get to is that the users will go through the knowledge base before they log a call and then they won't need to ring up. (Graham, Service Implementation Manager, Stoneworks)

The data revealed that these different attempts to commodify the IT professionals' knowledge were largely unsuccessful. The research participants were observed practising in highly contextualized, complex and dynamic technical environments. Such complex IT systems are prone to failure in multifarious ways. As such, the work might be characterized as being highly contingent, often extemporaneous, and requiring considerable mental flexibility when using technological expertise comprising theoretical and contextual elements (Trusson and Woods, 2017). The nature of the work is reflected in the following participant comments:

It's very complex, unbelievably so sometimes. All the [military client] stuff is highly configurable, and one option can change another one. It's very complicated, very high level technical expertise is needed. (Mike, Technical Systems Analyst, Poyet).

There are thousands of different applications, several thousand different users... we need to know about how the different operating systems work, how all the active directories work and that kind of thing. It's probably 60 percent organizational complexity and about 40 percent technical complexity. It certainly helps that a lot of the guys are MCSE or MCSA [Microsoft Certified Solutions Expert / Solutions Associate] qualified, and a couple are working towards networking qualifications. (Roger, Support and Installation Engineer, $\mathrm{SCC})$ 
This finding illustrates how the professionalism of these IT workers related to the individualized expertise they brought to the job. The observation data point to a characterization of the work as being in large part 'uncommodifiable' (Abbott, 1988, p.324), with the creative application of 'somewhat abstract knowledge to particular cases' (Abbott, 1988, p.8) being central to the professional performance.

The data revealed that, beyond the managerial constraints of the ICT-enabled labour process discussed above, IT professionals in the servitized IT function still needed sufficient autonomy to be able to satisfactorily fulfil their core technical-professional role of investigating and resolving incidents. In this self-reliant practice they drew on their expertise gained via heavily-contextualized experiential learning. By way of illustration, Lionel expressed the importance of self-reliance to his professional practice:

I've got quite a good memory for storing knowledge... I think of myself as quite intelligent and quite good at resolving issues by my own means. (Lionel, Senior Network Security Engineer, Server Control)

In practice the observed IT professionals at all sites typically recorded only brief resolution information (i.e. information to assist if similar incidents occurred in the future) within the incident record database (Table 3: T7). While the task of recording this information was technologically mandated by the workflow management system (Table 3: T2), they necessarily retained autonomy over what was written to the incident record. Similarly, despite management requesting IT professionals write 'knowledge articles' for a knowledge database system (Table 3: T8), this database could not assert technological agency to enforce compliance. Given that commoditising expertise in this way was therefore a discretionary act, and that the IT professionals were working self-reliantly under time pressures (as discussed 
previously), it is unsurprising that the data point to IT professionals resisting use of the knowledge system to add or seek objectified knowledge. This was evident from the observation data and particularly revealed by a monthly Stoneworks IM report. This reported that 6306 incidents were logged during the monthly period but that only eight new knowledge articles had been added to the database during that time. Interview data revealed that most IT professionals held a pessimistic view on the usefulness of the 'knowledge' in the knowledge system; for example, Stephen (Support and Installation Engineer, SCC) noted:

We do have a knowledge base where we can write articles, but it is sketchy, and it is not always up to date, and it's only as good as what you put into it, and where someone has written a knowledge base article you can pick holes in it, so you tend not to use it. You might use it as a building block to something else, but you wouldn't use it as the methodology to resolve a problem.

In contrast to managerial assumptions as to the value of commodified expertise, our data support Abbott's (1988) view that an important feature of professional work is professional inference. Here the obscure, individualized and contextualized experiential knowledge acquired over time is of crucial importance for making 'the connection between diagnosis and treatment' (Abbott, 1988, p.48), i.e. for investigating an incident through to resolving it. In the face of a managerial will to rationalize expertise via 'lean knowledge work' approaches (Staats and Upton, 2011), it is this 'uncommodifiable obscurity' that necessitates a self-reliant contemplative professional practice. Such a practice that scorns the use of tools introduced for the commodification of knowledge for reuse may be considered as a form of resistance. However, if it is, then the data here suggest it is one borne of professional concerns for: the quality of the technical performance, and personal technical-professional fulfilment. By contrast the data here do not suggest that it is defiant resistance to management authority as 
the ITSM 'best practice' literature implies (e.g. Lloyd, 2011; Rance, 2011). In the next section we further discuss these findings, with particular emphasis on how the research contributes to the academic literature.

\section{Discussion and Contributions}

The important role played by ICTs in the management and conduct of IT professional work in servitized organizational IT functions has been neglected in the contemporary academic literature. The findings of this study enhance understanding of the impact of ICTs on contemporary IT work, contributing to the literature in two ways. Firstly, it draws attention to the managerial control effects of ICTs on the labour processes of the servitized IT function. Secondly, it reveals how professional logics become infected by camouflaged managerial control logics that are inscribed within ICTs.

As our first contribution we note the centrality of ICTs to the servitization of organizational IT functions. The findings illustrate how such ICTs support managerial objectives of rationalization and system control. We have identified four camouflaged managerial control effects inscribed within the ICTs used by servitized IT professionals. Specific technologies were identified as having controlling effects by prescribing the labour process, and by placing constraints upon workers as to what tasks they could perform within the labour process. Others asserted managerial control by enabling surveillance over the labour process or by attempting to induce the capture of IT professional knowledge/expertise within it. These effects are represented diagrammatically in Figure 2, illustrating the degradation of IT professional job quality in the servitized IT function. We might note here the irony of these ICTs, as the fruits of the IT profession, degrading the work of IT professionals in a similar way to how other ICTs forced upon other professionals might degrade that work. Accordingly, the theoretical model in Figure 2, in conjunction with the analytical schema 
outlined in Table 2, might be usefully employed when analysing the relationship between other organizational professionals and the ICTs imposed upon their labour processes.

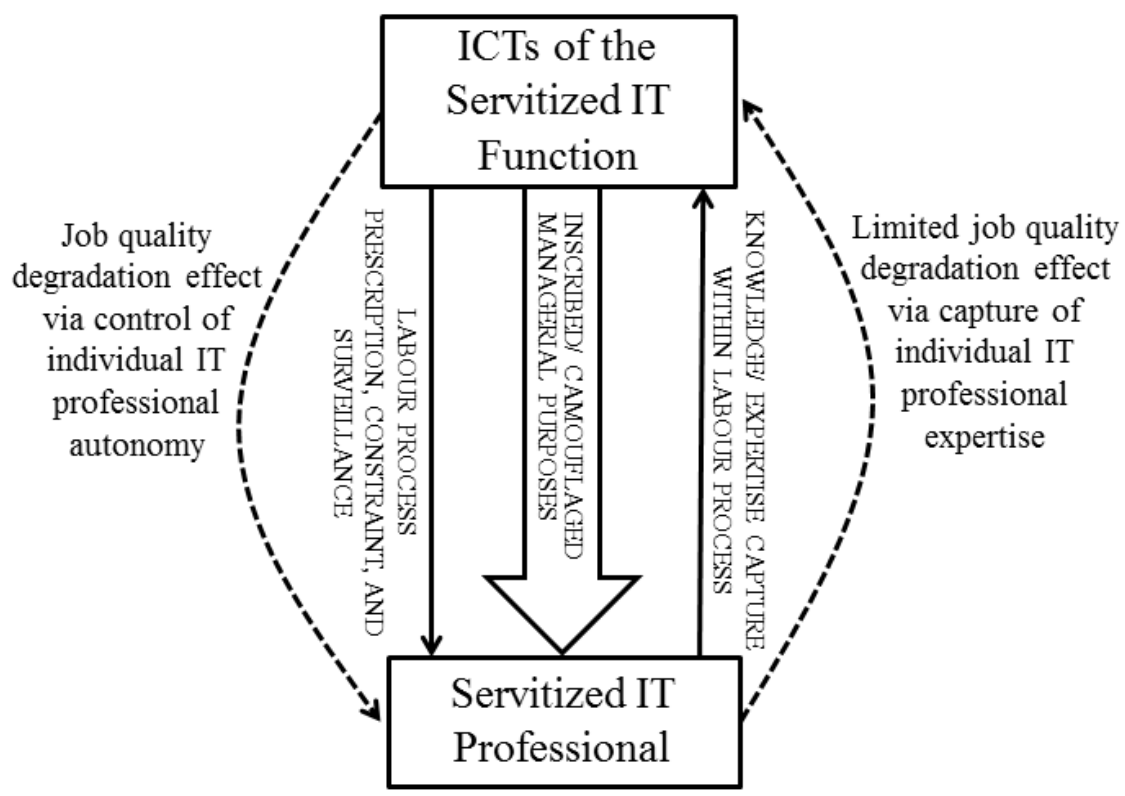

Figure 2: Model of relationship between ICTs and IT professionals in the servitized organizational IT function.

The left side of the diagram represents how some technologies not only prescribe the labour process for IT professionals but also place physical and mental constraints upon professional practice, and subject them to unremitting surveillance. This confirms that, just as in the healthcare organizational professional context (Petrakaki and Kornelakis, 2016), the imposition of ICTs into the servitized IT professional work arena facilitates the routinization of work and the limiting of individual autonomy and task discretion. Further, we suggest that job quality degradation and de-skilling in the IT professional work sphere results from such ICTs implicitly reducing opportunities to spend working hours obsessively 'doing something well for its own sake' as an act of 'mental craftsmanship' (Sennett, 2006, p.103-104). 
The right side of the diagram represents the effects upon IT professionals of other technologies introduced by managers to extract professional expertise for reuse by other workers. The inscribed knowledge codification and capture intent of these database technologies can be interpreted as a threat to the labour-market value of these professionals as aspects of their expertise becomes available to others. One aspect of the degradation of work via the employment of knowledge database systems (Taskin and Van Bunnen, 2015) is the implicit management expectation that workers refer to the database rather than self-reliantly practice using professional inference (Abbott, 1988). This expectation conceals a will to deskill and reduce opportunities for technical-professional development through problemsolving.

The findings illustrate how this managerial will, that emanates from a 'prevailing overrationalist view of knowing in organizations' (Nicolini, 2011, p. 617), is often thwarted in practice by IT professionals exercising 'professional discretion... to assert their professional judgement regarding advice, performance and treatment' (Evetts, 2002, p.345). This assertion of individuality highlights the importance of the human and social constituent elements of ICT artefacts (Orlikowski and Iacono, 2001), and suggests that the impact of knowledge database systems upon IT professional job quality may be limited. We might theorize here that individual IT professionals resist against managerial assaults on their professional autonomy. Perhaps a more significant explanation for failure to persuade IT professionals to commodify their expertise in a knowledge system is to be found in Hart's (1992) observation that experts are typically unable to verbalize their problem-solving activity unambiguously.

A second contribution to the literature emanating from the findings is the understanding that, through the mandated use of ICTs that are designed to serve managerial purposes, the operational/technical logics of IT professionals become 'infected' by oppositional managerial 
control logics (Faulconbridge and Muzio, 2008). This may have wider theoretical implications. The suggestion from this study is that ICTs can play a central role in shifting a profession away from a technical-professional logic towards a more commercial-professional logic that emphasizes achievement of management objectives over skilled performance (Spence and Carter, 2014). The technologies employed in the servitized IT function have enhanced managerial processes of control and rationality to encourage logics of functional practitionership directed towards fulfilment of quantitative SLA targets as 'commercial' evidence of providing a consistent 'professional' service (Sennett, 2008). We might reason that this inevitably undermines an individual's commitment to thorough exploration in professional practice. Here we are reminded of the distinction made by Sennett (2008, p.4546): 'to the absolutist... each imperfection is a failure; to the practitioner, obsession with perfection seems a prescription for failure'.

Drawing on Mintzberg's (1983) division of the bureaucratic form into a skills-oriented 'professional bureaucracy' and a process-oriented 'machine bureaucracy', the findings of this study suggest that the process-prescribing effects of ICTs may undermine the expertise-based authoritative status of IT professionals. This occurs through ICT-enabled and SLA-driven labour processes that prioritize speed of service restoration over concern for 'craftsmanship' (Sennett, 2008). From a managerial perspective, the allowance of sufficient labour-time to fully engage with a case (e.g. to identify and address the root cause of an incident) jeopardizes meeting agreed service levels (Steinberg, 2011). Developing technical skills through problem solving is a central concern of any technical professional discourse. Under IT servitization, enabled by ICTs, opportunities for IT professionals to problem solve are undermined, with de-skilling and reductions in job quality and professional status somewhat inevitable consequences.

\section{Conclusion}


This study has illustrated how ICTs have the capacity for degrading the job quality of IT professionals in the servitized IT function by asserting technical control through logics 'embedded in the technological structure' of their design (Edwards, 1979, p. 112). Theoretically, they might do this in two ways. Firstly, they might impinge upon the autonomy of professionals by prescribing work processes that constrain professional practice and through surveillance/performance monitoring mechanisms. Secondly, they might facilitate the commodification of aspects of expertise employed during professional practice, thus implicitly reducing reliance upon the embodied expertise of the technical professional. However, the data from this study suggest that managerial control benefits associated with knowledge capture are only achieved to a limited extent.

Our intent in conducting this multiple case-study research was to present a representative account of contemporary IT professional work through an in-depth empirical study of IT labour processes in servitized IT functions. A limitation of the study is that the qualitative data were collected from a particular group of IT professionals working in the servitized IT functions of five organizations in the UK. The data pertaining to this group is implicitly presented as representative of servitized IT professional work practices. As such further research along similar lines into similar work practices, and other professional work practices, is encouraged. Such research might illustrate how other ICTs have similar, or other, effects on job quality. More generally, further research along similar lines might have a cumulative effect of shifting our conception of what it is to be an organisational professional in an age when ICTs are central to the organisational professional performance (Susskind and Susskind, 2015).

Specifically, as a future research direction, we point to this study's potential implications for IT professionals being able to fulfil an important professional 'safeguarding' role (Freidson, 1994; Trusson and Woods, 2017) within servitized IT functions of organizations (including 
governmental) that have become dependent upon IT infrastructure. If the voice of the expert technical-professional is diminished via camouflaged managerial control mechanisms inscribed in ICTs then how will this impact on their assumed professional role of providing technical input to management decision-making?

\section{Acknowledgements}

Clive Trusson and Donald Hislop thank Debra Howcroft, Bob Russell, Diane Trusson and the two anonymous reviewers for their insights and constructive suggestions made during the preparation of this article. They also pay tribute to their friend and co-author, Neil F. Doherty (1959-2017). Before his untimely passing Neil was involved in the analysis of the research data and contributed key insights during the preparation of early versions of the article. 


\section{References}

Abbott, A. (1988), The System of Professions: An Essay on the Division of Expert Labour. (Chicago: University of Chicago Press).

Alvesson, M. (1987), Organisation theory and technocratic consciousness: rationality, ideology and quality of work. (New York: de Gruyter).

Ashburner, L. and L. Fitzgerald (1996), 'Beleaguered professionals: clinicians and institutional change in the NHS', in H. Scarbrough (ed.), The Management of Expertise (Basingstoke: MacMillan).

Bapna, R., N. Langer, A. Mehra, R. Gopal and A. Gupta (2013), 'Human Capital Investments and Employee Performance: An Analysis of IT Services Industry', Management Science 59, $3,641-658$.

Barley, S.R. and G. Kunda (2004), Gurus, Hired Guns, and Warm Bodies: Itinerant Experts in a Knowledge Economy. (Princeton, NJ: Princeton University Press).

Bartlett, J., D. Hinley, B. Johnson, D. Johnson, C. Keeling, V. Lloyd, I. MacDonald, J. Mather, G. McLaughlin, C. Rudd, D. Wheeldon and R. Young (2001), Service Delivery. (Norwich: TSO).

BCS [BCS: The Chartered Institute for IT] (2009), The case for ITIL® ${ }^{\circledR}$, http://www.bcs.org/content/conWebDoc/25457 (accessed 29th August, 2017).

Bergvall-Kåreborn, B. and D. Howcroft (2013), 'The future's bright, the future's mobile': a study of Apple and Google mobile application developers, Work, Employment and Society 27, 6, 964-981. 
Bloor, M. and F. Wood (2006), Keywords in Qualitative Methods: A Vocabulary of Research Concepts. (London: Sage).

Bocij, P., A. Greasley and S. Hickie (2008), Business Information Systems: Technology, Development and Management, $4^{\text {th }}$ Edition. (Harlow: Pearson Education).

Brannick, T. and D. Coghlan (2007), 'In Defense of Being "Native": The Case for Insider Academic Research', Organizational Research Methods 10, 1, 59-74.

Braverman, H. (1974), Labor and Monopoly Capital. The Degradation of Work in the Twentieth Century. (New York: Monthly Review Press).

Broadbent, J., M. Dietrich and J. Roberts (1997), The End of the Professions? The restructuring of professional work. (London: Routledge).

Brock, D.M. (2006), 'The Changing Professional Organization: A Review of Competing Archetypes', International Journal of Management Reviews 8, 3, 157-174.

Brock, D.M., H. Leblebici and D. Muzio (2014), 'Understanding professionals and their workplaces: The mission of the Journal of Professions and Organization', Journal of Professions and Organization 1, 1, 1-15.

Callaghan, G. and P. Thompson (2001), 'Edwards revisited: technical control and call centres', Economic and Industrial Democracy 22, 1, 13-37.

Cannon, D. (2011), ITIL: Service Strategy, $2^{\text {nd }}$ Edition. (Norwich: TSO).

Cater-Steel, A. (2009), 'IT service departments struggle to adopt a service-oriented philosophy', International Journal of Information Systems in the Service Sector 1, 2, 69-77.

Clarke, R. (1988), 'Information Technology and Dataveillance', Communications of the ACM 31, 5, 498-512. 
Cohen, L., A. Wilkinson, J. Arnold and R. Finn (2005), 'Remember, I'm the bloody architect!' Architects, organizations and discourses of profession', Work, Employment and Society 19, 4, 775-796.

Conger, S. (2010), 'From the Special Issue Editor: Servitizing IT', Information Systems Management 27, 2, 100-102.

Dimaggio, P.J. and W.W. Powell (1983), 'The iron cage revisited: institutional isomorphism and collective rationality in organizational fields.' American Sociological Review 48, 2, 147 60.

Edwards, R. (1979), Contested Terrain: The Transformation of the Workplace in the Twentieth Century. (New York: Basic Books).

Eisenhardt, K.M. (1989), 'Building theories from case study research', Academy of Management Review 14, 4, 532-550.

Eisenhardt, K.M. and M.E. Graebner (2007), 'Theory building from cases: Opportunities and challenges', Academy of Management Journal 50, 1, 25-32.

Emerson, R.M., R.I. Fretz and L.L. Shaw (1995), Writing Ethnographic Fieldnotes. (Chicago: University of Chicago Press).

Evetts, J. (2002), 'New directions in state and international professional occupations: discretionary decision-making and acquired regulation', Work, Employment and Society 16, $2,341-353$.

Evetts, J. (2003), 'The Sociological Analysis of Professionalism: Occupational Change in the Modern World', International Sociology 18, 2, 395-415. 
Faulconbridge, J. and D. Muzio (2008), 'Organizational professionalism in globalizing law firms'. Work, Employment and Society 22, 1, 7-25.

Feigenbaum, A.V. (1986), Total Quality Control. (New York: McGraw-Hill).

Fincham, R. (2006), 'Knowledge work as occupational strategy: comparing IT and management consulting', New Technology, Work and Employment 21, 1, 16-28.

Fournier, V. (2000), 'Boundary work and the (un)making of the professions', in N. Malin (ed) Professionalism, Boundaries and the Workplace. (London: Routledge).

Freidson E. (1994), Professionalism Reborn: Theory, Prophecy and Policy. (Cambridge: Polity Press).

Freidson, E. (2001), Professionalism, the third logic: on the practice of knowledge. (Chicago: University of Chicago Press).

George, M.L. (2003), Lean Six Sigma for Service: How to Use Lean Speed and Six Sigma Quality to Improve Services and Transactions. (New York, McGraw-Hill).

Greenhill, R. (2011), 'Preface', in Dutta, S. and Mia, I. The Global Information Technology Report 2010-11: Transformations 2.0. (Geneva: The World Economic Forum/INSEAD).

Hart, A. (1992), Knowledge Acquisition for Expert Systems, 2nd edition. (New York: McGraw-Hill).

Hawk, S., K.M. Kaiser, T. Goles, C.V. Bullen, J.C. Simon, C.M. Beath, K.P. Gallagher and K. Frampton (2012), ‘The Information Technology Workforce: A Comparison of Critical Skills of Clients and Service Providers', Information Systems Management 29, 1, 2-12. 
Hewlett Packard (2002), HP and the IT Infrastructure Library (ITIL): White Paper, HewlettPackard Company, http://www.devx.com/assets/vendshow/11384.pdf (accessed $17^{\text {th }}$ December, 2017).

Holman, D. (2013), 'Job types and job quality in Europe', Human Relations 66, 4, 475-502.

Howcroft, D. and B. Light (2006), 'Reflections on issues of power in packaged software selection', Information Systems Journal 16, 3, 215-235.

Hunnebeck, L. (2011), ITIL: Service Design, $2^{\text {nd }}$ Edition. (Norwich: TSO).

Iden, J. and T.R. Eikebrokk (2013), 'Implementing IT Service Management: a systematic literature review', International Journal of Information Management 33, 3, 512-533.

Iden, J. and L. Langeland (2010), 'Setting the Stage for a Successful ITIL Adoption: A Delphi Study of IT Experts in the Norwegian Armed Forces', Information Systems Management 27, 2, 103-112.

Johnson, T. (1972), Professions and Power. (London: Macmillan).

Katzenbach, J.R. and D.K. Smith (1994), The Wisdom of Teams: Creating the HighPerformance Organization. (Boston: Harvard Business School Press).

Korczynski, M. (2003), Human Resource Management in Service Work. (London: Palgrave Macmillan).

Kraft, P. (1977), Programmers and Managers: The Routinization of Computer Programming in the United States. (New York: Springer-Verlag).

Larson, M. (1977), The Rise of Professionalism: A Sociological Analysis. (Berkeley: University of California Press). 
Levitt, T. (1972), 'Production-line Approach to Service', Harvard Business Review 50, 5, 4152.

Lloyd, V. (2011), ITIL Continual Service Improvement, $2^{\text {nd }}$ Edition. (Norwich: TSO).

Marks, A. and D. Scholarios (2007), 'Revisiting technical workers: professional and organizational identities in the software industry', New Technology, Work and Employment 31, 1, 26-40.

McAfee, A. (2006), 'Mastering the Three Worlds of Information Technology', Harvard Business Review 84, 11, 141-149.

Miles, M.B. and A.M. Huberman (1994), Qualitative Data Analysis: An Expanded Sourcebook, $2^{\text {nd }}$ Edition. (Thousand Oaks: Sage Publications).

Mintzberg, H. (1983), Structure in Fives: Designing Effective Organizations. (Englewood Cliffs: Prentice-Hall).

Muzio, D., D.M. Brock and R. Suddaby (2013), 'Professions and Institutional Change: towards an Institutionalist Sociology of the Professions', Journal of Management Studies 50, $5,699-721$

Nicolini, D. (2011), 'Practice as the site of knowing: insights from the field of telemedicine', Organization Science 22, 3, 602-620.

Orlikowski, W.J. and C.S. Iacono (2001), 'Research Commentary: Desperately Seeking the "IT" in IT Research - A Call to Theorizing the IT Artifact', Information Systems Research 12, 2, 121-134.

Padgett, D.K. (1998), Qualitative Methods in Social Work Research: Challenges and Rewards. (Thousand Oaks: Sage). 
Petrakaki, D. and A. Kornelakis (2016), “We can only request what's in our protocol': technology and work autonomy in healthcare', New Technology, Work and Employment 31, 3, 223-237.

Pollard, C. and A. Cater-Steel (2009), 'Justifications, Strategies and Critical Success Factors in Successful ITIL Implementations in U.S. and Australian Companies: An Exploratory Study', Information Systems Management 26, 2, 164-175.

Rae, B. (2017), IT Service Management Survey, https://ciowatercooler.co.uk/ (accessed $4^{\text {th }}$ December, 2017).

Rance, S. (2011), ITIL: Service Transition, $2^{\text {nd }}$ Edition. (Norwich: TSO).

Russell, B. (2009), Smiling Down the Line: Info-Service Work in the Global Economy. (Toronto: University of Toronto Press).

Russell, B., C. Trusson and S. De (2016), 'The ambiguities of 'managed professionalism': working in and with IT", in A.Wilkinson, D. Hislop and C. Coupland (eds) Perspectives on Contemporary Professional Work: Challenges and Experiences. (Cheltenham: Edward Elgar).

Schutz, A. (1966), Collected Papers III: Studies in Phenomenological Philosophy, edited by I. Schutz. (The Hague: Marinus Nijhoff).

Schutz, A. (1970), On Phenomenology and Social Relations: Selected Writings, edited by H.R. Wagner. (Chicago: University of Chicago Press).

Sennett, R. (2006), The Culture of the New Capitalism: The Castle Lectures in Ethics, Politics, and Economics. (New Haven: Yale University Press).

Sennett, R. (2008), The Craftsman. (London: Penguin). 
So, J.C.F. and N. Bolloju (2005), 'Explaining the intentions to share and reuse knowledge in the context of IT service operations'. Journal of Knowledge Management 9, 6, 30-41.

Spence, C. and C. Carter (2014), 'An exploration of the professional habitus in the Big 4 accounting firms', Work, Employment and Society 28, 6, 946-962.

Staats, B.R. and D.M. Upton (2011), 'Lean Knowledge Work', Harvard Business Review, 85, $10,100-110$.

Standing, G. (2011), The Precariat: A New Dangerous Class. (London: Bloomsbury).

Starr, P. (1982), The Social Transformation of American Medicine. (New York: Basic Books).

Steinberg, R. (2011), ITIL: Service Operation, $2^{\text {nd }}$ Edition. (Norwich: TSO).

Stroud, R. (2011), 'Efficient, effective and just enough service management to drive business value', Service Talk, April 2011, 26-27.

Sturm, R., W. Morris and M. Jander (2000), Foundations of Service Level Management. Indianapolis: Sams.

Susskind, R. and D. Susskind (2015), The Future of the Professions: How Technology Will Transform the Work of Human Experts. (Oxford: Oxford University Press).

Taskin, L. and G. Van Bunnen (2015), 'Knowledge management through the development of knowledge repositories: towards work degradation', New Technology, Work and Employment 30, $2,158-172$.

Taylor, P. (2015), 'Labour and the Changing Landscape of the Call Centre', in K. Newsome, P. Taylor, J. Bair, and A. Rainnie (eds) Putting Labour in its Place: Labour Process Analysis and Global Value Chains. (London: Palgrave). 
Taylor, P. and P. Bain (1999), “An assembly line in the head': work and employee relations in the call centre', Industrial Relations Journal 30, 2, 101-117.

TCS Computer Services (2017), Policies and Standards, http://tcscs.co.uk/policies-andstandards/ (accessed 4th November, 2017)

Thompson, P. (1989), The Nature of Work: An Introduction to Debates on the Labour Process, $2^{\text {nd }}$ edition. (Basingstoke: Macmillan).

Trusson, C. and F. Woods (2017), 'An end to the job as we know it': how an IT professional has experienced the uncertainty of IT outsourcing', Work, Employment and Society, 31, 3, $542-552$.

Turban, E., R. Kelly Rainer Jr. and R.E. Potter (2001), Introduction to Information Technology. (New York: John Wiley \& Sons).

Webster, J. (1990), Office Automation: The Labour Process and Women's Work in Britain. (Hemel Hempstead: Harvester Wheatsheaf).

Winner, L. ([1980]1999), 'Do artifacts have politics?', in D. McKenzie and J. Wajcman (eds) The Shaping of Technology, $2^{\text {nd }}$ Edition. (Buckingham: Open University Press).

Winner, L. (1996), 'Electronic Office: Playpen or Prison', in R. Kling (ed) Computerization and Controversy, $2^{\text {nd }}$ Edition. (San Diego: Academic Press).

Winniford, M.A., S. Conger and L. Erickson-Harris (2009), 'Confusion in the Ranks: IT Service Management Practice and Terminology', Information Systems Management 26, 2, 153-163. 
Wipro (2017), Global Service Management.

http://www.wipro.com/india/offerings/professional-services/managed-it/global-servicemanagement/ (accessed 4th November, 2017)

Woodcock, J. (2017), Working the Phones: Control and Resistance in Call Centres. (London: Pluto Press).

Yin, R. (2014), Case Study Research: Design and Methods, $5^{\text {th }}$ Edition. (Thousand Oaks: Sage).

Zuboff, S. (1988), In the Age of the Smart Machine: The Future of Work and Power. (Oxford: Heinemann). 